\title{
Fetus exposure to HIV infection by mother during pregnancy - legal aspects
}

\author{
Marta Rorat ${ }^{1,2}$, Tomasz Jurek ${ }^{1}$ \\ ${ }^{1}$ Department of Forensic Medicine, Wroclaw Medical University, Wroclaw, Poland \\ ${ }^{2}$ Department of Medical Law, Wroclaw Medical University, Wroclaw, Poland
}

\begin{abstract}
From the medical and legal points of view, mother to child way of pathogens' transmission is specific. In case of human immunodeficiency virus (HIV), the highest risk of infection occurs during labor; hence, implementation of pharmacological prophylaxis for the mother and child is of high importance. Criminal law protection of a pregnant woman is of special nature, as it concerns two dependent entities, yet unequal before the law: the mother and the child. Legislators clearly give priority to the mother's life and health over the life and health of nasciturus. The beginning of labor or the moment when objective indications for early delivery occur, are considered to be the beginning of legal protection of life and health of a child, provided that the fetus has reached fetal viability. Only then, it is entitled to full legal protection. A HIV-infected woman who refuses therapy and, therefore, puts her child at risk of becoming infected, may be liable to prosecution. Liability under Article $161 \S 1$ of the Penal Code arises only when the child acquires the rights of a born person (human rights). Should the infection be transmitted in the perinatal period or after the birth, a mother may be held liable for moderate or even serious damage to the child's health. A physician is required by law to provide his patient with detailed information regarding the ways of HIV transmission, the options to protect the child against infection, and the risks associated with refusal to undergo therapy.
\end{abstract}

HIV AIDS Rev 2020; 19, 3: 147-152 DOI: https://doi.org/10.5114/hivar.2020.98005

Key words: AIDS, liability, crime, maternity.

\section{Introduction}

From the medical, social, psychological, and legal points of view, mother-to-child (MTC) human immunodeficiency virus (HIV) transmission, even though it occurs rarely (constituting only $0.3 \%$ of all infections in Poland [1]), is of specific nature. It is commonly known that a child can become infected at any stage of pregnancy, during labor, and breastfeeding. Without proper prophylaxis, the risk of infecting a child during pregnancy and labor is high, with about $15-30 \%$. However, if proper actions are taken promptly (administration of antiretroviral treatment to the pregnant

Address for correspondence: Prof. Tomasz Jurek, Department of Forensic Medicine, Wroclaw Medical University, 4 J. Mikulicza-Radeckiego St., 50-345 Wroclaw, Poland, e-mail: tomasz.jurek@umed.wroc.pl woman and administration of medication to her child after birth), the risk can be reduced to 1\% [2]. Approximately, 70\% of MTC HIV transmissions occur in the perinatal period, and intrauterine infections (through the placenta, after its formation, in the second or third trimester) represent merely few percent. Breastfeeding is the most common way of HIV transmission after birth, where the risk is approximately $1 \%$ per each month [3]. All medical actions are aiming not only at improving the mother's health, but also at reducing the risk of infection development in the child. Situations, in which HIV-infected women do not take care of neither their own health nor the health of their unborn children (risky
Article history:

Received: 17.09.2019

Received in revised form: 13.11.2019

Accepted: 15.11.2019

Available online: 30.07 .2020
International Journal of HIV-Related Problems

HIV \& AIDS

R e vi e w 
behaviors, not taking medication, not attending follow-up visits), are a challenge, even for experienced physicians. When reasonable arguments regarding the necessity to begin the treatment are not sufficient, it is natural for the physician to seek appropriate legal instruments - criminal law, in particular. In its part related to crimes against life and health, the currently applicable penal code contains several provisions penalizing behaviors that violate or pose a threat to the basic constitutional rights. Those rights encompass, among other things, human life and health as well as they concern also the nasciturus (unborn child, fetus). Moreover, Art. 161 of the Penal Code explicitly refers to an exposure to HIV infection. The question arises: what is the actual scope of criminal law protection? Is the interest of an unborn child properly protected?

The aim of the paper was to assess of the possible criminal law consequences for the mother putting her child at risk of HIV infection and the transmission of infection to a fetus or an infant.

\section{Brief description of the status of knowledge}

As world data show, as many as $30 \%$ of pregnant women are not tested for HIV during pregnancy, and another $15-20 \%$ do not receive proper prenatal care. In Poland, HIV infection has been so far diagnosed in more than 160 children (since 1985), but it is estimated that the actual number of infected children can be as high as 1,000. Approximately, $10 \%$ of minors become infected via the same ways as adults, mainly through intravenous drug use and sexual encounters. The remaining cases are MTC HIV infections [4]. Forty-seven cases of HIV infections in children of infected mothers, including 15 cases of AIDS and 7 deaths, were reported in Poland between 2009 and 2018 [1]. Over the years, a decrease in number of infections transmitted via MCT has been observed, which is associated with greater awareness of both medical staff and the entire society.

In Poland, in accordance with the ordinance of the Minister of Health of August 16, 2018 on the organizational standard of perinatal care [5], every pregnant woman should be referred for two HIV tests: the first one carried out until the $10^{\text {th }}$ week of pregnancy or at the time of first visit, and the second one, between the $33^{\text {th }}$ and $37^{\text {th }}$ week of pregnancy. Nevertheless, the HIV test results (from the $33^{\text {rd }}-37^{\text {th }}$ week of pregnancy) should be verified in every woman admitted to hospital for labor, and if no current test results are available, the woman should be tested immediately. Until 2018, such tests were only recommended; currently, they are mandatory. The labor of an HIV-infected woman should take place at a hospital with a ward of tertiary referral level of perinatal and neonatological care. Theoretically, the above standards should ensure the possibility of effective detection of HIV infections in pregnant women, and thus, application of proper treatment and prophylaxis. In practice, the implementation of these rules depends on a proper approach of a physician and cooper- ation of a pregnant woman. Apart from the sense of duty and responsibility, the awareness of the existence of legal standards that penalize both infection and, in specific situations, exposure to infection, can be helpful in terms of protecting the life and health of a child.

In case of pregnant women, criminal law protection is of specific nature, as it considers two individuals: the mother and the fetus. In Poland, legislation protects the interest of these two biologically inseparable and functionally interdependent entities in an unequal way. The life and health of the pregnant women is legally protected in full, whereas the life and health of the fetus is protected to a lesser extent. Pregnancy can be, for example, terminated for maternal and fetal indications, which obviously, signifies the interest of the mother, not that of the child. Another issue, crucial for these considerations, is the question of when full criminal law protection of life and health begins. It is important to specify the particular moment of fetal life, at which the nasciturus gains full legal protection and becomes a human being in a legal sense. It would seem that it takes place when the child separates from the mother's body. Such criterion is, however, insufficient as it does not provide full criminal law protection, e.g., in the case of medical errors committed during labor. Fundamental for doctrinal adjudication is the Act of the Supreme Court of October 26, 2006, in which the primacy of obstetric criterion was acknowledged. When asked: "Is the life and health of a child under criminal law protection provided for in Art. 160 of the Penal Code from the onset of labor or only from the moment of separating the child from the body of the mother, or from the moment the child begins to breathe with its own lungs?" the Court answered: "The object of protection provided for in Art. 160 of the Penal Code is the life and health of a person from the onset of labor (uterine contractions that cause progress of labor), and, in the case of caesarean section ending the pregnancy, from the moment of taking actions aimed at carrying out the procedure" [6]. Another decision of the Supreme Court of October 30, 2008 extended criminal law protection of the life and health of the unborn child. Apart from the two situations described above, such protection will also apply when: "Should medical necessity of carrying out the procedure of caesarean section or another alternative procedure aimed at ending pregnancy, from the moment medical indications for conducting such procedure occur" [7]. In summary, the beginning of legal protection of life and health is the onset of labor or the moment when objective indications for early delivery occur, under condition that the fetus has reached fetal viability [8].

So far, the issue of exposing fetus and a newborn child to HIV infection by the mother has not been an object of interest of the legal doctrine. The most thorough analyses come from the nineties, from the so-called "old penal code", and are now obsolete. It should be mentioned that Art. 162 of the Penal Code from 1969 covered the issue of exposure to venereal diseases, which were defined as three potential syphilis, gonorrhea, and venereal ulcer. Thus, it was not possible to impose penalties for exposure to HIV infection until 
the decree was abolished. Even then, the possibility of incurring liability for the offense of exposing from Art. 160 of the Penal Code was questioned, indicating the problem of the scope of legal protection of the unborn child under criminal law [9]. In the light of the current doctrine, the possibility of applying this provision to an HIV-infected woman/mother is hypothetical, and there are no such examples in the case law. It is not without a reason that the legislator introduced the offense of exposure to HIV (and other infectious diseases determined in the provision) into the new Penal Code, Art. 161.

$\$ 1$ of Art. 161 of the Penal Code states that whoever knowing that he or she is HIV-positive, directly exposes another person to HIV transmission and is liable to a penalty of deprivation of freedom ranging from 6 months to 8 years. The assumption of this provision is to penalize every behavior, in which (Art. 160 of the Penal Code assumes the possibility of unintentional exposure) a patient who is aware of his or her infection behaves in a way that puts other persons at risk of infection. It does not matter whether the exposed person has actually been infected, via which (direct) way the infection has been transmitted, and what the level of probability of transmitted infection was. Causing such risk alone is punishable (Table 1).

Analysis of several potential situations associated with the risk of HIV transmission (exposure) and the transmission of infection from the mother to the fetus or the child, is presented below.

\section{A woman who is aware of being infected with HIV becomes pregnant}

In legal literature, it is emphasized that an HIV-infected woman who becomes pregnant does not put the fetus at risk (during the pregnancy) as solely "another person" (identified as "human being" on the basis of interpretation under Art. 160 of the Penal 161 of the Penal Code), "a live born human being" or a human being in the process of delivery, or indications for it, can be a victim of an offense [10]. This does not apply to an unborn child. Therefore, regardless of the intent or whether the woman is taking antiretroviral medication or not, she will not incur liability under Art. 161 of the Penal Code, considering the possibility of committing such offense during the period of pregnancy. For the same reason, adopting classification under Art. 161 of the Penal Code is not applicable.

\section{A pregnant woman who was previously healthy engages in sexually risky behaviors, has unprotected sex with an HIV-infected person, or takes drugs intravenously}

In such situation, apart from the above-discussed issue related to the victim of the offense of exposure to infection, the factor that makes it impossible to adopt criminal clas- sification under Art. $161 \S 1$ of the Penal Code is the lack of a subject of criminal offense (only an infected person can constitute one) as well as the lack of directness of the action. In order to expose the fetus to HIV infection, the pregnant woman should first become infected, otherwise the exposure would be of indirect nature.

\section{A pregnant woman with diagnosed HIV-infection who is aware of being infected does not undergo therapy during pregnancy, but eventually agrees to treatment in the perinatal period}

As there is a close relationship between the maternal HIV viremia and the risk of infection transmission to the fetus, HIV diagnosis constitutes an absolute indication for proper antiretroviral therapy during pregnancy as well as for taking proper precautions during the labor (including selection of delivery method) and pharmacological prophylaxis of the neonate. This way, the risk can be reduced to as little as $1 \%$ [2]. In such situations, from the medical point of view, fetus exposure to infection definitely occurs; the risk of transmitting the virus during pregnancy (apart from the period of labor) is several percent. However, pressing charges neither under Art. 160 nor Art. 161 of the Penal Code is not possible due the lack of a subject of both types of offenses during the period of the pregnancy: a fetus is not a human being in the light of the provision; therefore, it is not entitled to full legal protection.

\section{A pregnant woman with diagnosed HIV infection, of which she is aware, does not undergo antiretroviral therapy during pregnancy, which results in the child becoming infected}

In such case, we are dealing with exposing the fetus to the risk of HIV infection and transmission of the virus to the fetus. Assuming intentional nature of mother's actions, one should consider the possibility of classification under Art. 157a of the Penal Code $\$ 1$, which states that "Any person who causes damage to an unborn infant or a disturbance to its health, which exposes its life to danger is liable to a fine, a penalty of restriction of freedom, or deprivation of freedom of up to 2 years". Infecting the fetus with HIV can be considered as a "exposes its life to danger". However, a detailed analysis of the structure of the provision makes it impossible to hold the pregnant woman criminally liable in practice. Due to the fact that $\$ 3$ of the cited provision contains the expression "the mother of the child is not liable to a penalty", the discussed action, even if the pregnant woman is the perpetrator, is not punishable by law, but it remains an offense. In theory, a person who helps a pregnant woman or who urges her to commit the offense by, for example, convincing her not to take the medications recommended 
Table 1. Polish Penal Code regulation, which might refer to an exposure to HIV infection

\begin{tabular}{|c|c|}
\hline Art. 160 & $\begin{array}{l}\S 1 \text {. Any person who exposes another person to a direct danger of loss of life or a severe impairment to his } \\
\text { health is liable to a penalty of deprivation of freedom of up to } 3 \text { years. } \\
\S 2 \text {. If the perpetrator has a duty of care over the person exposed to danger, he is liable to a penalty } \\
\text { of deprivation of freedom, ranging from } 3 \text { months to } 5 \text { years. } \\
\S 3 \text {. If the perpetrator of the act defined under } \S 1 \text { or } 2 \text { acts unintentionally, he is liable to a fine, a penalty } \\
\text { of restriction of freedom, or deprivation of freedom of up to } 1 \text { year. } \\
\S 4 \text {. A perpetrator who intentionally prevented the threatened danger is not liable to a penalty for the offence } \\
\text { defined under } \S 1 \text { to } 3 \text {. } \\
\S 5 \text {. The prosecution of the offence defined under } \S 3 \text { takes place at the request of the wronged person. }\end{array}$ \\
\hline Art. 161 & $\begin{array}{l}\S 1 \text {. Any person who, knowing that he is HIV-positive, directly exposes another person to HIV transmission, } \\
\text { is liable to a penalty of deprivation of freedom ranging from } 6 \text { months to } 8 \text { years. } \\
\S 2 \text {. Any person who, knowing that he is infected with a sexually-transmitted disease or a contagious, } \\
\text { or terminal disease, or a disease, which threatens a person with death and exposes directly another person } \\
\text { to its transmission, is liable to a penalty of deprivation of freedom ranging from } 3 \text { months to } 5 \text { years. } \\
\S 3 \text {. If the perpetrator of the act defined under } \S 2 \text { exposes many people to transmission is liable to a penalty } \\
\text { of deprivation of freedom, ranging from } 1 \text { to } 10 \text { years. } \\
\S 4 \text {. The offence defined under } \S 1 \text { or } 2 \text { is prosecuted at the request of the wronged person. }\end{array}$ \\
\hline Art. 156 & $\begin{array}{l}\text { § } 1 \text {. Any person who causes a severe impairment of health in the form of: } \\
\text { 1) depriving a person of sight, hearing, speech, fertility, } \\
\text { 2) causing another person's severe disability, severe terminal or long-term sickness, an illness exposing } \\
\text { him to the risk of death, a permanent mental illness, a total or significant permanent incapacity for } \\
\text { performing the profession/vocation or a permanent significant bodily distortion, or disfigurement, } \\
\text { is liable to a penalty of deprivation of freedom not shorter than } 3 \text { years. } \\
\S 2 \text {. If the perpetrator acts unintentionally, he is liable to a penalty of deprivation of freedom of up to } 3 \text { years. } \\
\S 3 \text {. If the consequence of the act defined under } \S 1 \text { is the death of a person, the perpetrator is liable to } \\
\text { a penalty of deprivation of freedom, ranging from a penalty of } 25 \text { years' custodial sentence or the penalty } \\
\text { of a life sentence. }\end{array}$ \\
\hline Art. 157 & $\begin{array}{l}\S 1 \text {. Any person who causes an impairment of bodily functions or disturbance to health other than that defined } \\
\text { under Art. } 156 \S 1 \text { is liable to a penalty of deprivation of freedom, ranging from } 3 \text { months to } 5 \text { years. } \\
\S 2 \text {. Any person who causes an impairment of the bodily functions or disturbance to health for a period of over } \\
7 \text { days is liable to a fine, a penalty of restriction of freedom, or of deprivation of freedom of up to } 2 \text { years. } \\
\S 3 \text {. If the perpetrator of the act defined under } \S 1 \text { or } 2 \text { acts unintentionally, he is liable to a fine, a penalty } \\
\text { of restriction of freedom, or of deprivation of freedom of up to } 1 \text { year. } \\
\S 4 \text {. The prosecution of the offence defined under } \S 2 \text { or } 3 \text { if the impairment of the bodily function or } \\
\text { the disturbance to health lasted up to } 7 \text { days, takes place based on a private accusation unless } \\
\text { the wronged person is living together with perpetrator. } \\
\S 5 \text {. If the wronged person is the next of kin, the offence defined under } \S 3 \text { is prosecuted at the request of this } \\
\text { person. }\end{array}$ \\
\hline Art. $157 a$ & $\begin{array}{l}\S 1 \text {. Any person who causes damage to an unborn infant or a disturbance to its health, which exposes its life to } \\
\text { danger is liable to a fine, a penalty of restriction of freedom, or deprivation of freedom of up to } 2 \text { years. } \\
\S 2 \text {. No offence is committed by a doctor if the bodily impairment or disturbance to the health of an unborn } \\
\text { child is the consequence of treatment necessary to prevent the danger to which the health or life } \\
\text { of the pregnant woman or unborn infant is exposed. } \\
\S 3 \text {. The mother of an unborn infant is not liable to a penalty when she commits an act defined under } \S 1 \text {. }\end{array}$ \\
\hline
\end{tabular}

by her [9] physician or a physician who, in spite of knowing that such medications are necessary, does not recommend them, or does not refer the pregnant woman to proper consultation, could be criminally liable. HIV infection, however, does not cause any typical symptoms in the fetus and is diagnosed only after birth. Apart from a situation, in which a child has detectable viremia immediately after birth, there is no possible way of proving that it was during pregnancy, not during labor, that the "damage to an unborn infant or a disturbance to its health, which exposes its life to danger" occurred.

\section{A pregnant woman with diagnosed HIV infection, of which she is aware, refuses to undergo prophylactic procedures during labor - antiretroviral treatment}

In this case, in accordance with the currently adopted jurisprudence that considers the moment the labor starts as the beginning of legal protection of life and health of a child, it is possible to classify the deed as direct exposure to HIV infection under Art. $161 \S 1$ of the Penal Code. Directness 
of the exposure is associated with the way of infection, including MTC and via blood, specifically, high-risk of transmitting the infection from the mother to the child regardless of delivery method, occurs during labor. As it is an intentional crime, it will be important to determine whether the pregnant woman was aware of the transmission ways, the danger and the risk for the fetus, and it is strictly associated with the question of whether and to what extent the physician complied with his obligation to provide information.

\section{An HIV-infected woman who is aware of her condition does not agree to postpartum treatment and, despite the instructions not to do so, breastfeeds the child}

As Zielińska and Budyn-Kulik et al. indicated, a mother who is breastfeeding her child can be responsible for exposing her child to the risk of HIV infection $[9,11]$. It is certain that a neonate is entitled to full legal protection of its life and health, and it can, therefore, be the victim of offense under Art. $161 \$ 1$ of the Penal Code. The woman must be aware that HIV can also by transmitted by breast milk and, should she agree to the possibility of infecting her child or, alternatively, infect the child on purpose, it will entail criminal liability. Just like in the cases to the afore-mentioned behaviors, it is important whether the information regarding the ways of infection transmission and the possibilities of preventing infection has been effectively communicated to the patient by the physician.

\section{An HIV-infected woman who is aware of her condition infects her child during labor or breastfeeding}

In case when the child becomes infected due to maternal negligence (for example, lack of perinatal prophylaxis, breastfeeding despite lack of treatment, or ineffectiveness of therapy), the mother may be liable for causing moderate impairment of health (Art. $157 \$ 1$ ) or severe impairment of health (Art. $156 \$ 1$ point 2 of the Penal Code) [9]. Importantly, natural course of HIV infection in children is different than in adults; it is, first and foremost, more rapid and less predictable. The greatest risk concerns younger children and children with severe immunodeficiency. The risk of AIDS development in children below 6 months of age is $>10 \%$, and between the 6th and the $24^{\text {th }}$ month of age, it increases by another $5-10 \%$ [3].

From the medical point of view, it is the role of physician taking care of a pregnant HIV-positive patient (both the infectious disease specialist and the obstetrician) to protect the fetus/child against infection. In order to achieve this goal, the mother not only has to be aware of the risk, but she must also properly cooperate and comply with appropriate recommendations of her doctor. Naturally, for the patient to follow the recommendations, the physician must provide her with proper information regarding the risk and transmission ways, as compliance will largely depend on meeting this obligation.

The right to information is one of the basic rights of the patient, and its scope is determined in Art. 9 of the Act on Patient's Rights [12]. The patient is entitled to obtain understandable information on his/her health, diagnosis, suggested and possible diagnostics, therapeutic methods, predictable outcome of their application or omission, treatment results, and prognosis from the physician (or another person practicing the medical profession in accordance with his/her competences). If the physician is suspecting or has diagnosed an infectious disease, he is obliged to inform the infected patient about measures of transmission prevention [13]. For evidential reasons (it does not, however, result from the provisions of the law), if an HIV-infected woman refuses a treatment, the doctor should enter the information about having met the obligation to provide his patient with information in her medical history, and the patient should personally sign such entry. Failure to meet the obligation to provide information is associated with the risk of incurring civil liability for violation of patient's right. In addition, should the infection be transmitted from the mother to the child, if the risk could have been reduced to an extremely low level, liability related to damaging the health of the child can be incurred.

The physician is not obliged to inform the patient about the possibility of incurring criminal liability for exposing or infecting the child. Such argument, however, can be used in the conversation with the infected patient, if she refuses to acknowledge other reasonable arguments. Importantly, should exposure to infection occur, the physician is not legally bound (under Art. 240 of the Penal Code) to file a notification of suspected offence. The physician's sole obligation is the so-called social or moral obligation. It is not the role of the physician to assess whether in each situation, there are any prerequisites for committing a crime of exposure to HIV or damage to health associated with transmission of infection. The authors recommend informing the law enforcement authorities about every situation of the life and health of both a fetus and a child being put at risk due to maternal negligence.

\section{Conclusions}

According to the current law, a pregnant woman who refuses treatment shall not be criminally liable for direct or indirect exposure of the unborn child to HIV infection during pregnancy. Liability under Art. $161 \$ 1$ of the Penal Code can arise at earliest during the labor (or the moment indications for early delivery occur, provided that the fetus has reached viability), or during breastfeeding and postnatal care. If HIV is transmitted to a child after its birth, the mother commits an offense of impairment of health (disturbances to health) under Art. $156 \S 1$ or $157 \S 1$ of the Penal Code. To assess the degree of mother's predictability, it is necessary to con- 
sider whether the physician properly met the obligation to inform the patient about the ways and risk of transmission and prevention methods. If proper information was not provided, it can be considered a medical error (related to communication).

\section{Conflict of interest}

The authors declare no conflict of interest with respect to the research, authorship, and/or publication of this article.

\section{References}

1. www.pzh.gov.pl (Accessed: 30.08.2019).

2. Coutsoudis A, Kwaan L, Thomson M. Prevention of vertical transmission of HIV-1 in resource-limited settings. Expert Rev Anti Infect Ther 2010; 8: 1163-1175.

3. http://www.aids.gov.pl/kampanie/1 test.2zycia/strefadlakobiet/ matkaidzieckoahiv.html (Accessed: 30.08.2019).

4. Rahangdale L, Cohan D. Rapid human immunodeficiency virus testing on labor and delivery. Obstet Gynecol 2008; 112: 159-163.

5. The Regulation of the Minister of Health of 16 August 2018 on the Organizational standard of perinatal care, Journal of Laws 1756; 2018.

6. Resolution of the Supreme Court of 26 October 2006, ref. I KZP 18/06, OSNKW 11 (2006), 90.

7. Resolution of the Supreme Court of 30 October 2008, ref. I KZP 13/08, OSNKW 11 (2008), 90.

8. Jurek T. Opiniowanie sądowo-lekarskie w przypadkach narażenia na bezpośrednie niebezpieczeństwo utraty życia albo ciężkiego uszczerbku na zdrowiu. $1^{\text {st }}$ ed. Wrocław: Wydawnictwo Uniwersytetu Wrocławskiego; 2013.

9. Zielińska E. AIDS i ciąża - problemy prawnokarne. In: Szwarc AJ (ed.). AIDS i prawo karne. Poznań: Wydawnictwo Poznańskie; 1996, pp. 106, 109.

10. Kokot R. Komentarz do rozdziału XIX - Przestępstwa przeciwko życiu i zdrowiu.. In: Stefański RA (ed.). Kodeks karny. Komentarz 2016 r. Warszawa: Legalis; 2019.

11. Budyn-Kulik M, Michalski B, Pikulski S, Potulski J. Komentarz do art. 161 kodeksu karnego. In: Warylewski J (ed.). Przestępstwa przeciwko dobrom indywidualnym. System Prawa Karnego. Warszawa: Legalis; 2012.

12. The Act of 6 November 2008 on Patient's Rights and Patient's Right Spokesman, Journal of Laws 849; 2020.

13. The Act of 5 December 2008 on Preventing and Combating Infections and Infectious Diseases among People, Journal of Laws 1239; 2019. 